\title{
Comparison of expression systems for the extracellular production of mannanase Man23 originated from Bacillus subtilis B23
}

Haiyan Zhou, Yong Yang, Xu Nie, Wenjiao Yang and Yongyao Wu

\begin{abstract}
Background: Mannanase is an enzyme that can catalyze random hydrolysis of beta-1,4-mannosidic linkages in the main chain of mannans, glucomannans and galactomannans which are the key polymers in hemicellulose. It has been used in a number of different industrial applications including food, feed, pharmaceutical, pulp/paper industries, and second generation biofuel. To optimize the expression system of mannanase Man23 gene, two kinds of vectors and host bacteria were determined and compared.

Results: Recombinants pHY-p43-man23 and pBPS-man23 were constructed and transferred into Bacillus subtilis WB600 and Brevibacillus brevis respectively. For mannanase Man23 gene, recombinant pHY-p43-man23 expressed in Brevibacillus brevis had higher production and activity. Compared to the wild-type Bacillus subtilis B23, the production of recombinant pHY-p43-man23 in B. brevis increased by 10 times and activity increased by $21.3 \%$. pHY-p43-man23 in B. brevis had activity at the range of $20 \sim 70^{\circ} \mathrm{C}$ but its optimum temperature was $50^{\circ} \mathrm{C}$ and had activity from $\mathrm{pH} 4 \sim 10$ but its optimum $\mathrm{pH}$ was around 7 . This demonstrated the recombinant had improved stability as well.

Conclusions: Mannanase is an important industrial enzyme and combination of vector pHY-p43 and host Brevibacillus brevis is a novel expression system for a mannanase decoding gene. This work aims at exploring a better expression system of mannanase Man23 decoding gene for industrial application.
\end{abstract}

Keywords: Mannanase, Recombinant gene, Host bacterium, Expression system

\section{Background}

$\beta$-Mannanase, an extracellular enzyme, has hemicellulase activity or the activities of both hemicellulase and cellulase [1]. Mannanase can catalyze random hydrolysis of beta-1,4-mannosidic linkages in the main chain of mannans, glucomannans and galactomannans which are the key polymers in hemicellulose [2]. It is widely used by industries including food processing, feed, oil mining, paper making, pharmaceutical, and second generation biofuel $[3,4]$. It is especially involved in breaking down plant tissues by degrading mannan polymers in the cell walls [5].

Mannanases once were isolated from plants [6], marine mollusk [7], and a body of bacteria and fungi $[8,9]$.

\footnotetext{
* Correspondence: sws001@163.com
College of Bioscience and Biotechnology, Hunan Agricultural University,
Changsha 410128, China

* Correspondence: sws001@163.com
College of Bioscience and Biotechnology, Hunan Agricultural University,
Changsha 410128, China * Correspondence: sws001@163.com
College of Bioscience and Biotechnology, Hunan Agricultural University,
Changsha 410128, China
}

C Biomed Central

(c) 2013 Zhou et al.; licensee BioMed Central Ltd. This is an Open Access article distributed under the terms of the Creative Commons Attribution License (http://creativecommons.org/licenses/by/2.0), which permits unrestricted use, distribution, and reproduction in any medium, provided the original work is properly cited. The Creative Commons Public Domain Dedication waiver (http://creativecommons.org/publicdomain/zero/1.0/) applies to the data made available in this article, unless otherwise stated.

According to the hydrophobic cluster analysis of reported mannanases, they have been classified into glycoside hydrolase (GH) families 5 and 26. In this paper, mannanase Man23 which originated from Bacillus subtilis B23 belongs to family 26 .

Wild-type mannanase Man23 has high activity and stability. We found that the sites of H129, E159, H190, E191, W196, F197, W198, and W199 on mannanase Man23 are relevant to the activity and substrate binding. The mutations at the sites of H129, H190, and W198 increased activity by 3.5-, 2.2-, and 3.8-fold, respectively (Haiyan Z, Xu N, Yong Y, Wenjiao Y, Yongyao W: Engineering mannanase Man23 decoding gene from Bacillus Subtilis B23 by semi-rational design, submitted). Herein, in order to promote the production and stability for meeting its commercial usage, our team had a further study to optimize the expression system of mannanase Man23. We evaluated two vectors, pHY-p43 and pBKE50, 
and two host bacteria, Bacillus subtilis (B. subtilis) WB600 and Brevibacillus brevis (B. brevis), to figure out how the recombinant expression plasmids performed in the two novel hosts. This work provides insights into how an optimized expression system worked on mannanase Man23 gene and moreover, it throws a clue to select a more suitable expression system and a host bacterium for cellulase or hemicellulase gene.

\section{Results}

\section{Comparison of gene man23 expressed in host $B$. subtilis WB600 and B. brevis}

For the economical reason, it is necessary to construct the stable expression systems for producing recombinant proteins. At present, about $60 \%$ of the commercially available enzymes are produced by Bacillus species [10]. In comparison of Escherichia coli (E. coli), B. subtilis is an attractive host for enzyme production since it is nonpathogenic and has a high capacity of secreting extracellular proteins directly into the medium [11]. However, $B$. subtilis greatly reduces the production and intactness of the secreted proteins because of it secrets at least seven extracellular proteases [12]. A series of extracellular-protease-deficient Bacillus strains were improved as a cell factory for secreting target proteins.

B. subtilis WB600 is a six-extracellular-protease-deficient strain and it was shown that in this strain, protein degradation is minimized and the production of some proteins was improved compared to that in the wildtype [13].

B. brevis is a naturally extracellular-protease-deficient strain and has been known to exhibit high productivity of heterologous proteins into the culture medium but produce little extracellular protease [14,15], which enables a high recovery of the target proteins with minimal degradation. Thus it has been used as a good host for production of heterologous proteins. Importantly, these two hosts have the clearly-known metabolic background.

The gene man 23 using pHY-p43 as the expression vector firstly was introduced into the two hosts $B$. subtilis WB600 and B. brevis. The production yield of total proteins and mannanase Man23 in different hosts was shown in Figure 1. In comparison to the wild-type, B. bacillus WB600 and B. brevis displayed a better ability to express gene man23. The production of total proteins in B. bacillus WB600 and B. brevis increased by $12 \%$ and $16 \%$, meanwhile, the production of mannanase Man23 increased by 9.8 -fold and 10.5-fold and mannanase activity increased by $21 \%$ and $21.3 \%$ respectively.

SDS-PAGE was used to identify the secreted protein from different hosts and the result was shown in Figure 2. From the diagram, B. subtilis WB600 and B. brevis displayed their excellent and high-efficient production for mannanase Man23. Especially, B. brevis had a clearer

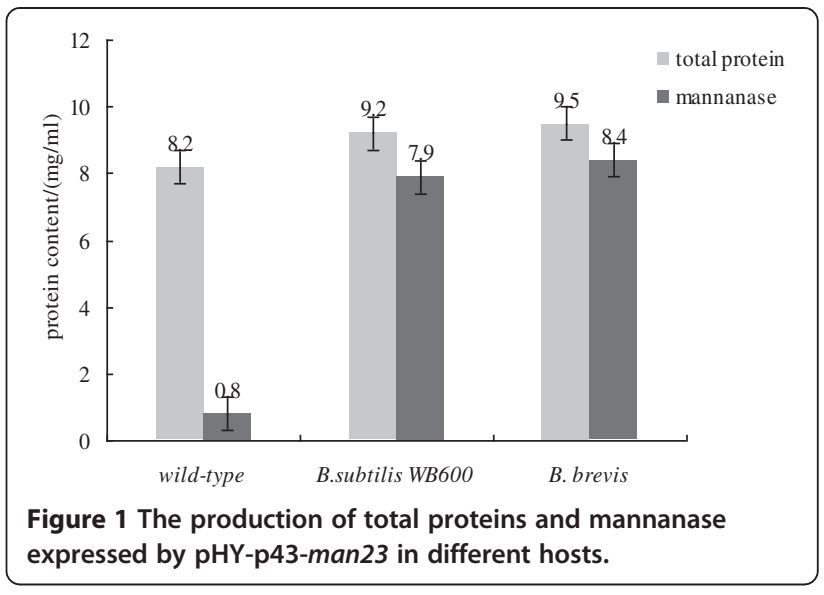

electrophoresis background compared to WB600 and wild-type host, which suggested $B$. brevis produced more mannanase Man23 and less other proteins. Thus, the purity of mannanase Man23 from B. brevis was highest among the tested hosts. In comparison with $B$. subtilis WB600 and B. brevis, the total protein production in $B$. brevis was higher than B. subtilis WB600 by $3 \%$ and mannanase Man23 production was higher by 6.3\%. Table 1 demonstrated the mannanase activity produced in $B$. brevis was higher than B. subtilis WB600 by $0.6 \%$.

Considering the data above and mannanase purity, $B$. brevis has been used as the host for expressing gene man 23 in our following work.

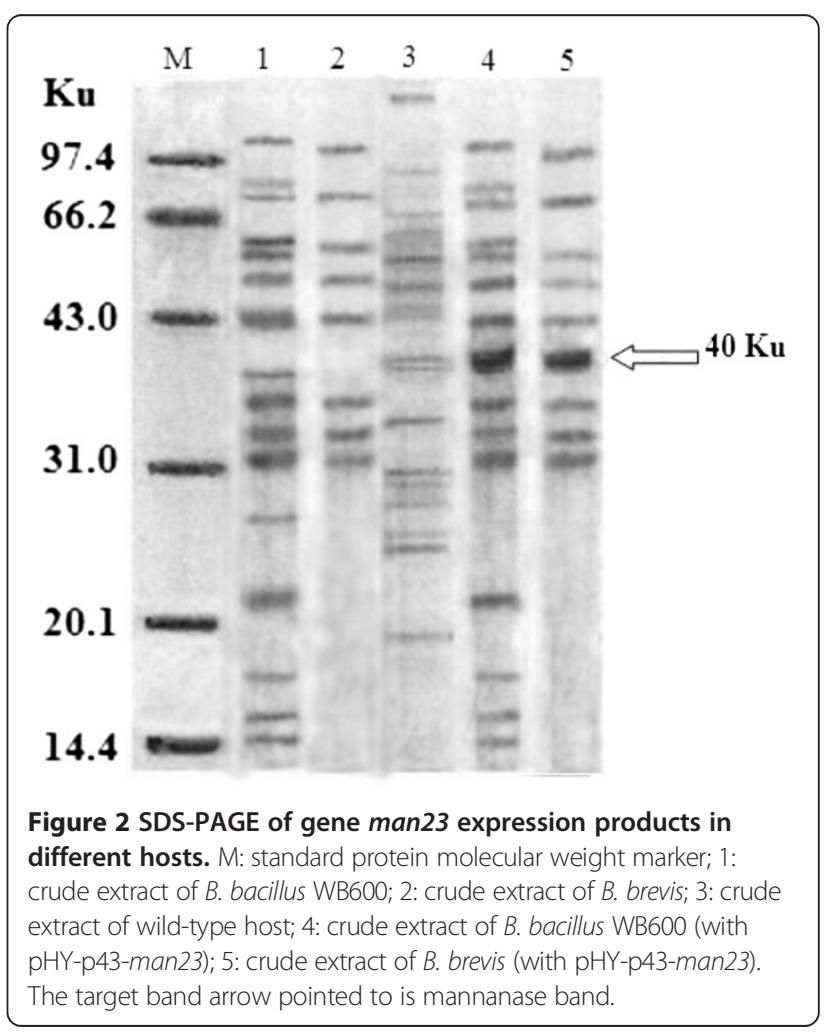


Table 1 Comparison of mannanase activity produced by pHY-p43-man23 in different hosts

\begin{tabular}{cc}
\hline Host bacterium & Mannanase activity(U/mg) \\
\hline Wild-type & $177.43 \pm 0.5$ \\
B. bacillus WB600 & $214 \pm 0.3$ \\
B. brevis & $215.3 \pm 0.5$ \\
\hline
\end{tabular}

\section{Comparison of the expression vectors pHY-p43 and pBKE50 for gene man23}

Plasmid pBKE50 is a shuttle vector which includes the replication origin of pUB110 and the erythromycinresistance gene of pGK12. Plasmid pHY-p43 is also a shuttle vector which includes the strong promoter P43. In our work, these two vectors were introduced to express gene man23 in B. brevis.

Mannanase Man23 encoding gene was identified to be $1100 \mathrm{bp}$ and was registered on Genbank [16]. Gene man23 was cloned using primer P1 and P2 to add $B a m H$ I and EcoR I restriction sites for the link with vector pHY-p43 and using primer P3 and P4 to add $B a m H$ I and Kpn I restriction sites for the link with vector pBKE50.

Both recombinants, pHY-p43-man23 and pBPS-man23, had excellent performance when they transformed into the host $B$. brevis and the results about production yield and mannanase activity of these two recombinants were shown in Table 2. Apparently, both recombinants produced much more mannanase and higher activity. The amount of total proteins expressed by pHY-p43-man 23 and pBPS-man 23 was enhanced by $19 \%$ and $4 \%$ compared to the wild-type. Moreover, comparing to the wild-type, the amount of mannanase Man23 increased by 11.25-fold and 8.05 -fold and the mannanase activity increased by $18 \%$ and $3.4 \%$ respectively. From the data, it can be easily figured out that pHY-p43-man23 had more proteins production by $14.45 \%$, more mannanase production by nearly $40 \%$ and higher mannanase activity by $14 \%$ than pBPS-man23. For this reason, in our following work, pHY-p43 has been used as the vector to express gene $\operatorname{man} 23$.

Table 2 Comparison of the production yield and mannanase activity produced by different expression plasmids

\begin{tabular}{lccc}
\hline $\begin{array}{l}\text { Expression } \\
\text { plasmid }\end{array}$ & $\begin{array}{c}\text { The amount of } \\
\text { total protein } \\
(\mathbf{m g} / \mathbf{m l})\end{array}$ & $\begin{array}{c}\text { The amount of } \\
\text { mannanase Man23 } \\
(\mathbf{m g} / \mathbf{m l})\end{array}$ & $\begin{array}{c}\text { Mannanase } \\
\text { activity } \\
\mathbf{( U / m g )}\end{array}$ \\
\hline Wild-type & $8.0 \pm 0.06$ & $0.72 \pm 0.02$ & $188.5 \pm 0.3$ \\
pHY-p43-man23 & $9.5 \pm 0.05$ & $8.1 \pm 0.05$ & $222.5 \pm 0.2$ \\
pBPS-man23 & $8.3 \pm 0.05$ & $5.8 \pm 0.03$ & $195 \pm 0.2$ \\
\hline
\end{tabular}

Biochemical characteristics of recombinant mannanase Man23 expressed by pHY-p43-man23 in host $B$. brevis

To obtain the details about recombinant mannanase Man23, herein we determined its biochemical characteristics. It had activity at the temperature range of $20 \sim$ $70^{\circ} \mathrm{C}$ and its optimum temperature is $50^{\circ} \mathrm{C}$ (Figure 3). When the recombinant Man23 had been maintained at different temperature for 20 hours, it displayed high stability at temperature of $20 \sim 40^{\circ} \mathrm{C}$ and reduced sharply at $50^{\circ} \mathrm{C}$ in 20 hours (Figure 3). Compared to the wild-type which had the optimum temperature $45^{\circ} \mathrm{C}$ and the activity range of $30 \sim 60^{\circ} \mathrm{C}$, the recombinant mannanase Man23 displayed a broader temperature range with high activity and a better heat tolerance.

Meanwhile, the optimum $\mathrm{pH}$ of wild-type was 6.5 and it had activity in the $\mathrm{pH}$ range of $4 \sim 9$. Nevertheless, recombinant mannanase Man23 had activity in a broader $\mathrm{pH}$ range of $4 \sim 10$ and its optimum $\mathrm{pH}$ shifted slightly to around pH 7 (Figure 4). When being reserved in the phosphate buffer of $\mathrm{pH} 5 \sim 7$ for 20 hours, the recombinant Man23 still kept $90 \%$ of activity but when out of pH $5 \sim 7$ it was not very stable (Figure 4).

The kinetic parameters of recombinant Man23 degrading locust bean gum were determined in $50 \mathrm{mmol} / \mathrm{L}$ phosphate buffer of $\mathrm{pH} 7.0$ at $50^{\circ} \mathrm{C}$. Through the Lineweaver-Burk Plot, the values of $K_{m}$ and $V_{\text {max }}$ were $0.38 \mathrm{mg} \cdot \mathrm{ml}^{-1}$ and $301 \mu \mathrm{mol} \cdot \mathrm{mg}^{-1} \cdot \mathrm{min}^{-1}$.

\section{Discussion}

Endo-1,4- $\beta$-Mannanase has been classified into two glycosyl hydrolase families, GH family 5 and 26, according to the amino acid sequence similarities and hydrophobic cluster [17]. From the sequence analysis, mannanase Man23 mentioned in this paper belongs to family GH26.

There have been some reports about the optimization of expression system and the characterization of recombinant mannanase as summarized in Table 3. The optimal $\mathrm{pH}$, temperature and the stability of mannanases reported were varying depending on the sources. Some mannanases screened by Katrolia P. [18] and Songsiriritthigul C. [2] had similar enzyme characteristics with mannanase Man23 and mannanase screened by Vu TT [19] had similar optimum $\mathrm{pH}$ with mannanase Man23 but the latter had broader $\mathrm{pH}$ activity range and higher thermo-stability. The activity and kinetic parameters of the mannanases from different sources varied greatly mainly because there are lots of differences with the structure of these mannanases. Usually, some thermostable mannanases tend to have lower specific activity in comparison with their mesophilic counterparts [20]. When comparing to other mannanases, it worth to be noticed that different substrates and individual techniques whittled down the accuracy for evaluating mannanase activity. 

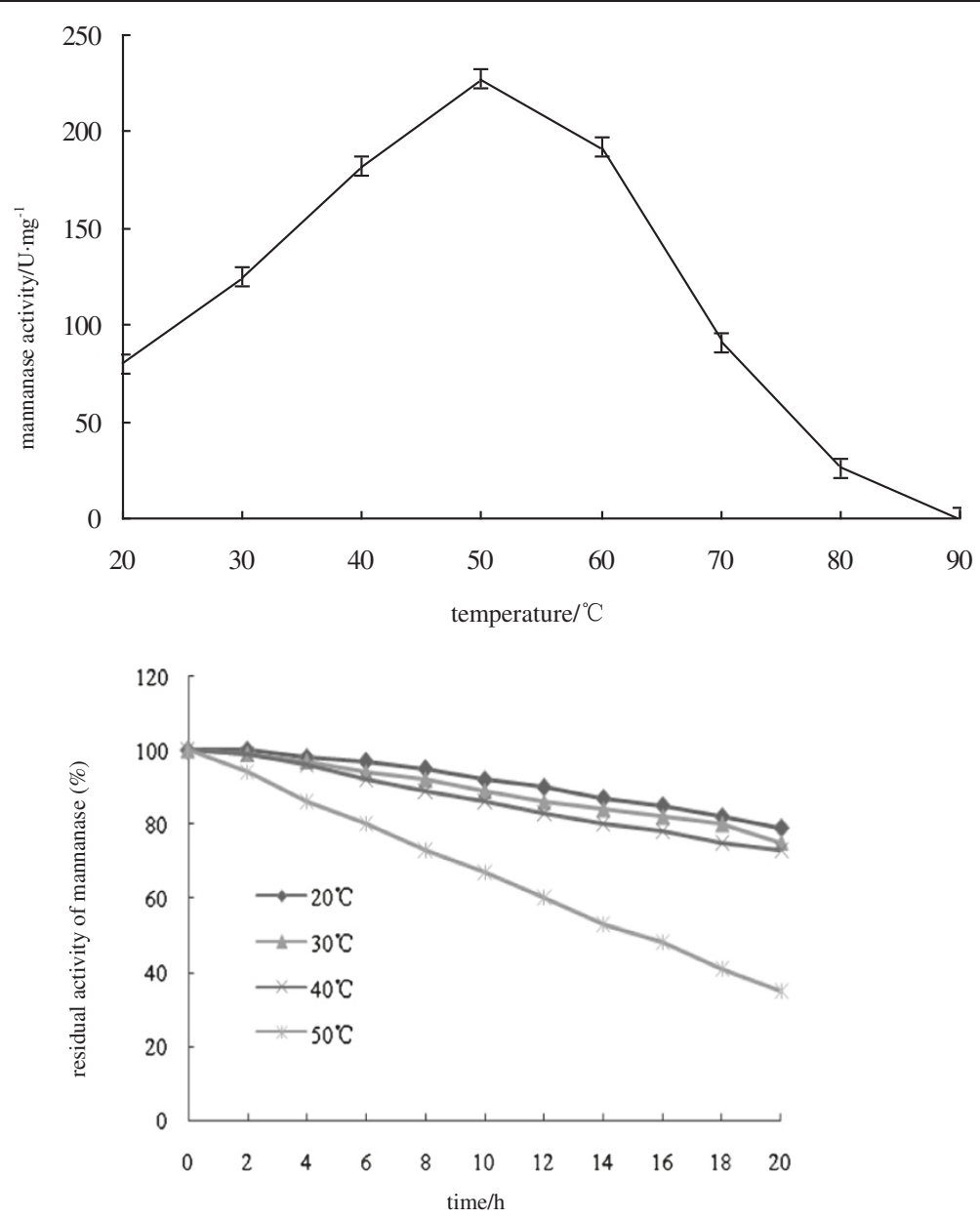

Figure 3 Effects of temperature on activity and stability of recombinant mannanase Man23.

From the references, mannanase encoding gene from different organisms was transformed to express in prokaryotic cells such as E. coli and B. subtilis and eukaryotic cells such as yeasts. Mannanase Man23 encoding gene was hardly secreted from E. coli, therefore E. coli would not be a good option if the secretary proteins were expected. Moreover, the secretion of proteins would simplify the extraction procedure. Both B. subtilis WB600 and $B$. brevis are effective hosts for secretary proteins since there are abundant of vectors and regulatory elements for Bacillus species to help proteins folding [33,34]. B. brevis especially has its advantages to be the expression host for gene man 23 because $B$. brevis can secrete disulfidebond-promoting factors to help proteins folding [35]. In our previous work, mannanase Man23 was found one disulfide bond formed between Cys90 and Cys110. Actually, our results about two tested hosts demonstrate $B$. brevis is more suitable for gene man 23 indeed. Eukaryotic cells usually have the capacity to express extracellular proteins efficiently. However, considering the economic reasons, prokaryotic cells have their advantages because of the shorter production period and the simpler extraction process compared to that of eukaryotic cells.

Each expression host has one or more applicative vectors. Some reported mannanase genes used their native expression vector, and while some were recombined into other vectors. Vector pJ $27 \Delta 88 \mathrm{U}$ was tested and suitable for use in B. subtilis 168. In our work, plasmid pBKE50 and $\mathrm{pHY}-\mathrm{p} 43$ are the shuttle vectors of $E$. coli and Bacillus. For gene man23, the promoter $\mathrm{p} 43$ on the vector $\mathrm{pHY}-\mathrm{p} 43$ showed high efficiency to manipulate mannanase Man23 encoding gene in $B$. brevis. It deserves the further researches on other applicable vectors for gene man 23 expression in B. brevis.

\section{Conclusions}

The system composed of vector pHY-p43 and host $B$. brevis is a novel expression system for mannanase encoding gene. Our results demonstrate that this novel system is efficient for expressing and secreting mannanase Man23 encoding gene, which deserves to be considered for indus- 

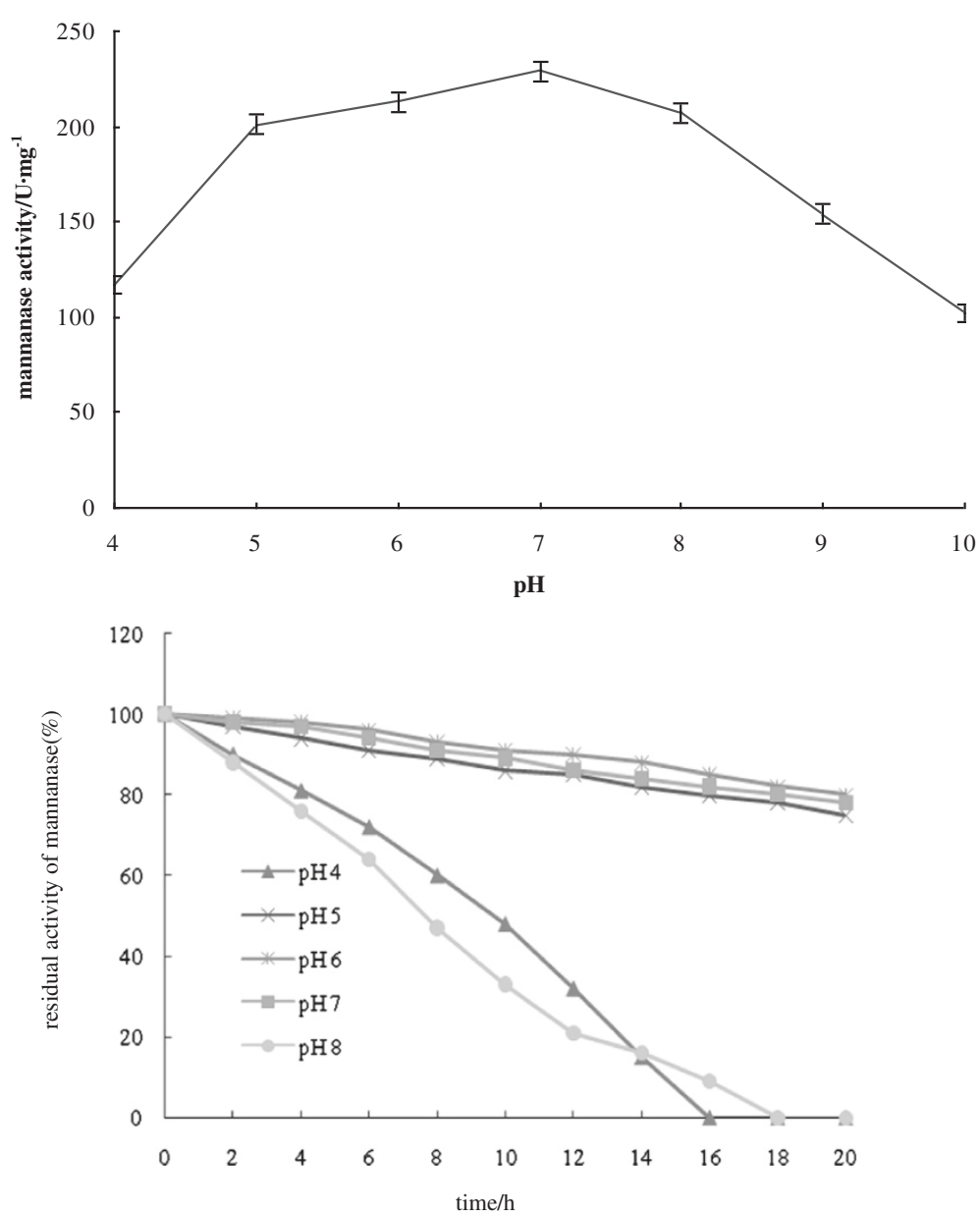

Figure 4 Effects of $\mathrm{pH}$ on activity and stability of recombinant mannanase Man23.

trial applications. Additionally, this expression system could be adopted for producing other enzymes as well.

\section{Methods}

Extraction of genomic DNA and plasmid DNA

Genomic DNA was extracted by SDS method [36] and plasmid DNA was extracted by alkaline lysis method [37].

\section{Cloning of mannanase Man23 encoding gene}

Through the sequence alignment with high homology, two couples of primers were designed to clone mannanase Man23 encoding gene from the whole DNA of wild-type. One couple used to clone the decoding gene linked with vector pHY-p43 is P1:5'-CGCGGATCCATGCCTACTA AGT-3' (underline is BamH I restriction site) and P2:5'CGGAATTCTGATTCAGCTATCTGTG-3' (underline is $E c o R$ I restriction site). The other couple used to clone the decoding gene linked with vector pBKE50 is P3:5'CGCGGATCC ATGCCTACTA AGT-3' (underline is BamH I restriction site)and P4:5' -GGGGTACCTGATT CAGCT ATCTGTG-3' (underline is Kpn I restriction site).
The PCR reaction is $94^{\circ} \mathrm{C}$ for $5 \mathrm{~min}$, followed by 30 cycles of $94^{\circ} \mathrm{C}$ for $30 \mathrm{~s} ; 56^{\circ} \mathrm{C}$ for $30 \mathrm{~s} ; 72^{\circ} \mathrm{C}$ for $1 \mathrm{~min}$, then $72^{\circ} \mathrm{C}$ for $10 \mathrm{~min}, 4^{\circ} \mathrm{C}$ thereafter. Cloning products were detected and recycled according to reference [38].

\section{Construction of expression plasmid pHY-p43-man23}

Plasmid pHY-p43-man23 was constructed from plasmid pHY-p43 and gene man 23 with BamH I and EcoR I restriction sites. The plasmid pHY-p43 (CICIM MMB0050) was purchased from CICIM-CU. The procedure of construction was represented in Figure 5.

\section{Construction of expression plasmid pBPS-man 23}

Plasmid pBPS-man 23 was constructed from plasmid pBKE50 and gene man23 with BamH I and Kpn I restriction sites. Plasmid pBKE50 was constructed basing on initial plasmids pKF3 [39] and pUB110 [40]. After digestion and re-link, the intermediate plasmid pKF33 was linked with erythromycin-resistance gene $\left(\mathrm{Em}^{\mathrm{r}}\right)$ to form plasmid pKF34. Another couple of primers, P5 and P6, were designed to clone the decoding gene of 
Table 3 Properties of various mannanase recombinants

\begin{tabular}{|c|c|c|c|c|}
\hline $\begin{array}{c}\text { Organism } \\
\text { (wild-type/expression host) }\end{array}$ & $\begin{array}{c}\text { Family } \\
\text { GH }\end{array}$ & $\begin{array}{l}\text { Expression vector } \\
\text { or plasmid }\end{array}$ & $\begin{array}{l}\text { Properties of recombinant } \\
\text { mannanase }\end{array}$ & Ref \\
\hline Stearothermophilus/ E. coli & & Plasmid pH6EX3 & $\begin{array}{l}\text { The recombinant had thermostability similar to the native enzyme; The values of } \\
V_{\max } \text { and } \mathrm{K}_{m} \text { were } 384 \mathrm{U} / \mathrm{mg} \text { and } 2.4 \mathrm{mg} / \mathrm{ml} \text {. }\end{array}$ & {$[21]$} \\
\hline $\begin{array}{l}\text { Bacillus circulans CGMCC } \\
1416 / \text { E. coli }\end{array}$ & GH5 & $\mathrm{pET}-22 \mathrm{~b}(+)$ & The activity was $481.55 \mathrm{U} / \mathrm{mg}$, the optimal temperature was $58^{\circ} \mathrm{C}$ and $\mathrm{pH}$ was 7.6 . & {$[22]$} \\
\hline B. subtilis Bs5/ E. coli & & & $\begin{array}{l}\text { The optimal temperature was } 35^{\circ} \mathrm{C} \text {, the optimal } \mathrm{pH} \text { was } 5.0 \text { and } \mathrm{pH} \text { range was } \\
\text { wide from } 3.0-8.0 \text {. }\end{array}$ & {$[23$} \\
\hline $\begin{array}{l}\text { Bacillus sp. JAMB-750/ } \\
\text { B. subtilis }\end{array}$ & $\mathrm{GH} 26$ & & The optimal pH was around pH 10. & {$[24]$} \\
\hline B. subtilis WL-3/B. subtilis 168 & $\mathrm{GH} 26$ & Vector pJ27 $\Delta 88 \mathrm{U}$ & The mannanase activity reached a maximum level of $450 \mathrm{U} / \mathrm{ml}$. & {$[25$} \\
\hline $\begin{array}{l}\text { Aspergillus sulphureus/ } \\
\text { P. pastoris }\end{array}$ & GH5 & & $\begin{array}{l}\text { The highest activity was at } \mathrm{pH} 2.4 \text { and } 50^{\circ} \mathrm{C} ; \mathrm{pH} \text { range was } 2.2-8.0 \text {; it was stable } \\
\text { below } 40^{\circ} \mathrm{C} \text {. The } \mathrm{K}_{m} \text { and } \mathrm{V}_{\max } \text { values for locust bean gum at } 50^{\circ} \mathrm{C} \text { and } \mathrm{pH} 2.4 \\
\text { were } 0.93 \mathrm{mg} / \mathrm{mL} \text { and } 344.83 \mathrm{U} / \mathrm{mg} \text {, respectively. }\end{array}$ & {$[26$} \\
\hline $\begin{array}{l}\text { Bispora sp. MEY-1/ P. } \\
\text { pastoris }\end{array}$ & GH5 & & $\begin{array}{l}\text { The recombinant was acidophilic with highest activity at } \mathrm{pH} \text { 1.0-1.5; the optimal } \\
\text { temperature was } 65^{\circ} \mathrm{C} \text {; The specific activity, } \mathrm{K}_{\mathrm{m}} \text { and } \mathrm{V}_{\text {max }} \text { for locust bean gum } \\
\text { was } 3,373 \mathrm{U} / \mathrm{mg}, 1.56 \mathrm{mg} / \mathrm{ml} \text {, and } 6,587.6 \mathrm{mmol} / \mathrm{min} / \mathrm{mg} \text {, respectively. }\end{array}$ & {$[2$} \\
\hline $\begin{array}{l}\text { B. subtilis strain G1/ } \\
\text { P. pastoris GS115 }\end{array}$ & & & $\begin{array}{l}\text { The recombinant had an optimum temperature of } 45^{\circ} \mathrm{C} \text { and optimum } \mathrm{pH} \text { of } 6.5 \text {; } \\
\text { the enzyme was stable at temperatures up to } 50^{\circ} \mathrm{C} \text { (for } 8 \mathrm{~h} \text { ) and in the } \mathrm{pH} \text { range } \\
\text { of 5-9. }\end{array}$ & \\
\hline $\begin{array}{l}\text { Humicola insolens Y1/ } \\
\text { P. pastoris }\end{array}$ & $\mathrm{GH} 5$ & & $\begin{array}{l}\text { The recombinant had a specific activity of } 1,122 \mathrm{U} / \mathrm{mg} \text { and exhibited optimal } \\
\text { activity at pH } 5.5 \text { and } 70^{\circ} \mathrm{C} \text {; it had excellent pH stability at pH 5.0-12.0 and } \\
\text { was highly thermostable at } 50^{\circ} \mathrm{C} \text {. }\end{array}$ & {$[2$} \\
\hline $\begin{array}{l}\text { Penicillium freii } \mathrm{F} 63 / \\
\text { P. pastoris }\end{array}$ & GH5 & & $\begin{array}{l}\text { The recombinant was optimal at } \mathrm{pH} 4.5 \text { and } 60^{\circ} \mathrm{C} \text { and exhibited good stability } \\
\text { over a broad } \mathrm{pH} \text { range from acidic to alkaline }(>85.0 \% \text { activity at } \mathrm{pH} 4.0-9.0,>70.0 \% \\
\text { activity at } \mathrm{pH} 10.0 \text { and } 43.7 \% \text { even at } \mathrm{pH} 12.0) \text {. }\end{array}$ & {$[2$} \\
\hline $\begin{array}{l}\text { B. subtilis MAFIC-S11/ } \\
\text { P. pastoris }\end{array}$ & & & $\begin{array}{l}\text { The expression level was improved by } 2 \text {-fold; the recombinant enzyme showed its } \\
\text { highest activity of } 24,600 \mathrm{U} / \mathrm{ml} \text { after } 144-h \text { fermentation; the optimal temperature } \\
\text { and } \mathrm{pH} \text { were } 50^{\circ} \mathrm{C} \text { and } 6.0 \text {, respectively; the specific activity was } 3,706 \mathrm{U} / \mathrm{mg} \text {; the } \\
\text { kinetic parameters } V_{\text {max }} \text { and } \mathrm{K}_{m} \text { were determined as } 20,000 \mathrm{U} / \mathrm{mg} \text { and } 8 \mathrm{mg} / \mathrm{mL} \text {, } \\
\text { respectively. }\end{array}$ & {$[30]$} \\
\hline $\begin{array}{l}\text { Aspergillus aculeatus/ } \\
\text { Aspergillus oryzae }\end{array}$ & & Vector pYES2.0 & The $\mathrm{pH}$ optimum was $\mathrm{pH} 5.0$ and a temperature optimum was $60-70^{\circ} \mathrm{C}$. & {$[31]$} \\
\hline $\begin{array}{l}\text { Bacillus sp. N16-5/ } \\
\text { Kluyveromyces cicerisporus }\end{array}$ & & & $\begin{array}{l}\text { The maximum yield of recombinant reached } 3,795 \mathrm{U} / \mathrm{ml} \text {; it exhibited similar pH } \\
\text { optima, temperature optima, and substrate specificities to its wild-type; its stability } \\
\text { was about } 7 \% \text { higher than that of wild-type from pH 9-11 and had about } 10 \% \\
\text { higher stability than wild-type from } 60^{\circ} \mathrm{C} \text { to } 80^{\circ} \mathrm{C} \text {. }\end{array}$ & [32] \\
\hline
\end{tabular}

$\Delta$ : delta, Vector pJ $27 \Delta 88 \mathrm{U}$ is a plasmid with a strong $B$. subtilis promoter.

the promoter and signal peptide of B. brevis. P5 is $5^{\prime}-\mathrm{C}$ CCAAGCTTCGTGAG AATGCGTACCAAA-3' (underline is Hind III restriction site) and P6 is $5^{\prime}$-TCCCCCG GGCGAAAGCCATGGGAGCAAC-3' (underline is Sma $I$ restriction site). The PCR reaction was $94^{\circ} \mathrm{C}$ for $5 \mathrm{~min}$, followed by 30 cycles of $94^{\circ} \mathrm{C}$ for $40 \mathrm{~s} ; 60^{\circ} \mathrm{C}$ for $30 \mathrm{~s} ; 72^{\circ} \mathrm{C}$ for $50 \mathrm{~s}$, then $72^{\circ} \mathrm{C}$ for $5 \mathrm{~min}, 4^{\circ} \mathrm{C}$ thereafter. The decoding gene of the promoter and signal peptide (PS) of B. brevis and plasmid pKF34 were digested with Hind III and Sma $I$ and then linked together to form the shuttle vector pBKE50. The details of construction procedure were represented in Figure 6.

Transformation and expression of the recombinant plasmids B. bacillus WB600 and B. brevis are both the Bacillus species hosts, therefore the approaches recombinant plasmids transforming into the hosts are similar and elaborated as following.

The host cells were shaking cultured in T2 medium [41] overnight at $37^{\circ} \mathrm{C}$ and then cultures were refreshed into $5 \mathrm{ml}$ of $\mathrm{T} 2$ medium by $1 \%$ of incubation amount and continued culturing till the late stage of logarithmic growth. The host cells were collected and suspended in $5 \mathrm{ml}$ of $50 \mathrm{mmol} / \mathrm{L}$ Tris- $\mathrm{HCl}(\mathrm{pH} \mathrm{7.5)}$ for a while and then cultured in $5 \mathrm{ml}$ of $50 \mathrm{mmol} / \mathrm{L}$ Tris- $\mathrm{HCl}(\mathrm{pH} \mathrm{8.5)}$ at $37^{\circ} \mathrm{C}$ for one hour. The host cells were collected into $0.5 \mathrm{ml}$ of TP medium (phosphate buffer $\left(1.905 \mathrm{~g} \mathrm{KH}_{2} \mathrm{PO}_{4}\right.$, $0.852 \mathrm{~g} \mathrm{Na}_{2} \mathrm{HPO}_{4}, 100 \mathrm{ml}$ ) mixed with $2 \times \mathrm{T} 2$ medium in proportion of $1: 1$ ) and at the same time, $100 \mu \mathrm{l}$ of TE/TP buffer (TE buffer(10 mmo1/L Tris-HCl, pH 7.5 and $1 \mathrm{mmo} / \mathrm{L}$ EDTA) mix with TP medium in proportion of 1:1) blended with $20 \mathrm{ul}$ recombinant plasmids of $10 \mathrm{ng} /$ $\mathrm{ul}$ and $1.5 \mathrm{ml}$ PEG solution (PEG6000 400 g, $500 \mathrm{ml}$ 


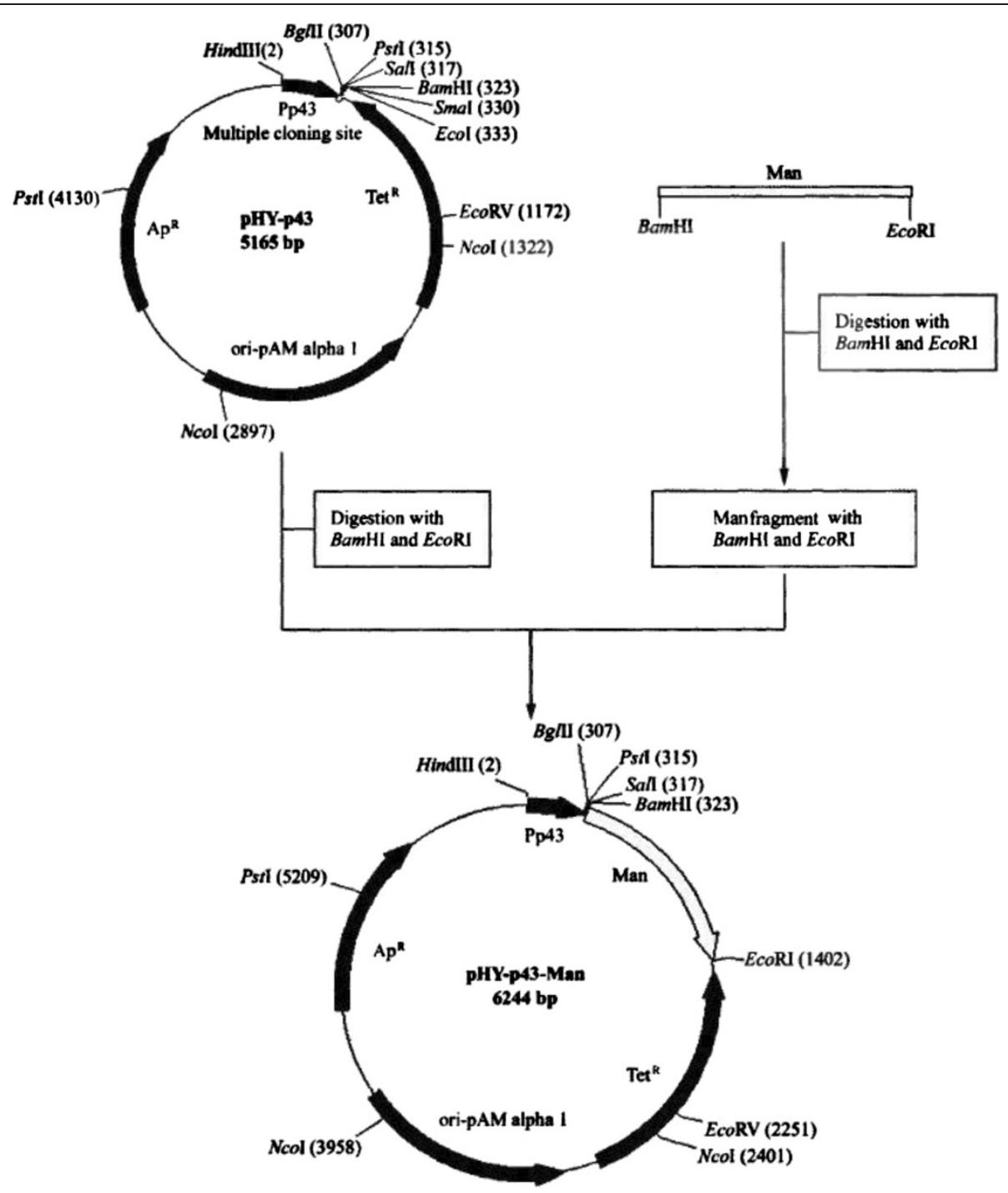

Figure 5 The construction of expression plasmid pHY-p43-man23.

phosphate buffer). The mixture was incubated at $37^{\circ} \mathrm{C}$ for $10 \mathrm{~min}$ and then the host cells were recollected into $1 \mathrm{ml} \mathrm{MT}$ medium $\left(\mathrm{MgCl}_{2}\right.$ in $\mathrm{T} 2$ medium with final concentrate of $20 \mathrm{mmol} / \mathrm{L}$ ) and agitated at $37^{\circ} \mathrm{C}$ for 30 min. After antibiotics Amp of $50 \mathrm{ug} / \mathrm{ml}$ and Tet of 40 $\mathrm{ug} / \mathrm{ml}$ were added into MT medium, the cultivation was continued for another $2 \mathrm{~h}$. The plate cultures with $100 \mathrm{ug} / \mathrm{ml}$ of Amp and $60 \mathrm{ug} / \mathrm{ml}$ of Tet were used successively to screen individual colonies.

Isolation of native and recombinant mannanase Man23 Crude proteins were prepared from supernatant after centrifuge and then successively purified through salting-out, molecular sieve chromatography Sephadex G-100 and ion-exchange column chromatography. The isolation procedure was carried out according to reference [42].
Determination of recombinant mannanase activity and biochemical characteristics

Protein concentration was measured using the Bradford assay [6]. Mannanase activity assay was improved from the method of reducing sugar assay $[43,44]$. One unit of enzyme activity was defined as the amount of enzyme liberating $1 \mu \mathrm{mol}$ mannose per minute at $50^{\circ} \mathrm{C}$ and $\mathrm{pH}$ 6.8. The activity formula was as follows:

Mannanase activity $(\mathrm{U} / \mathrm{ml})=5.56 \mathrm{C}_{\mathrm{e}} \mathrm{V}_{\mathrm{de}} / \mathrm{V}_{\mathrm{je}} \mathrm{V}_{\mathrm{s}} \mathrm{t}$

5.56 the mole value of $1.0 \mathrm{mg}$ mannose, $\mu \mathrm{mol}$

$\mathrm{C}_{\mathrm{e}}$ amount of mannose produced from hydrolysis, $\mathrm{mg}$

$\mathrm{V}_{\text {de }}$ metered volume of enzyme solution, $\mathrm{ml}$

$\mathrm{V}_{\mathrm{je}}$ volume of enzyme solution added into the reaction mixture, $\mathrm{ml}$

$\mathrm{V}_{\mathrm{s}}$ volume of substrate solution, $\mathrm{ml}$

$\mathrm{t}$ time, $\min$ 


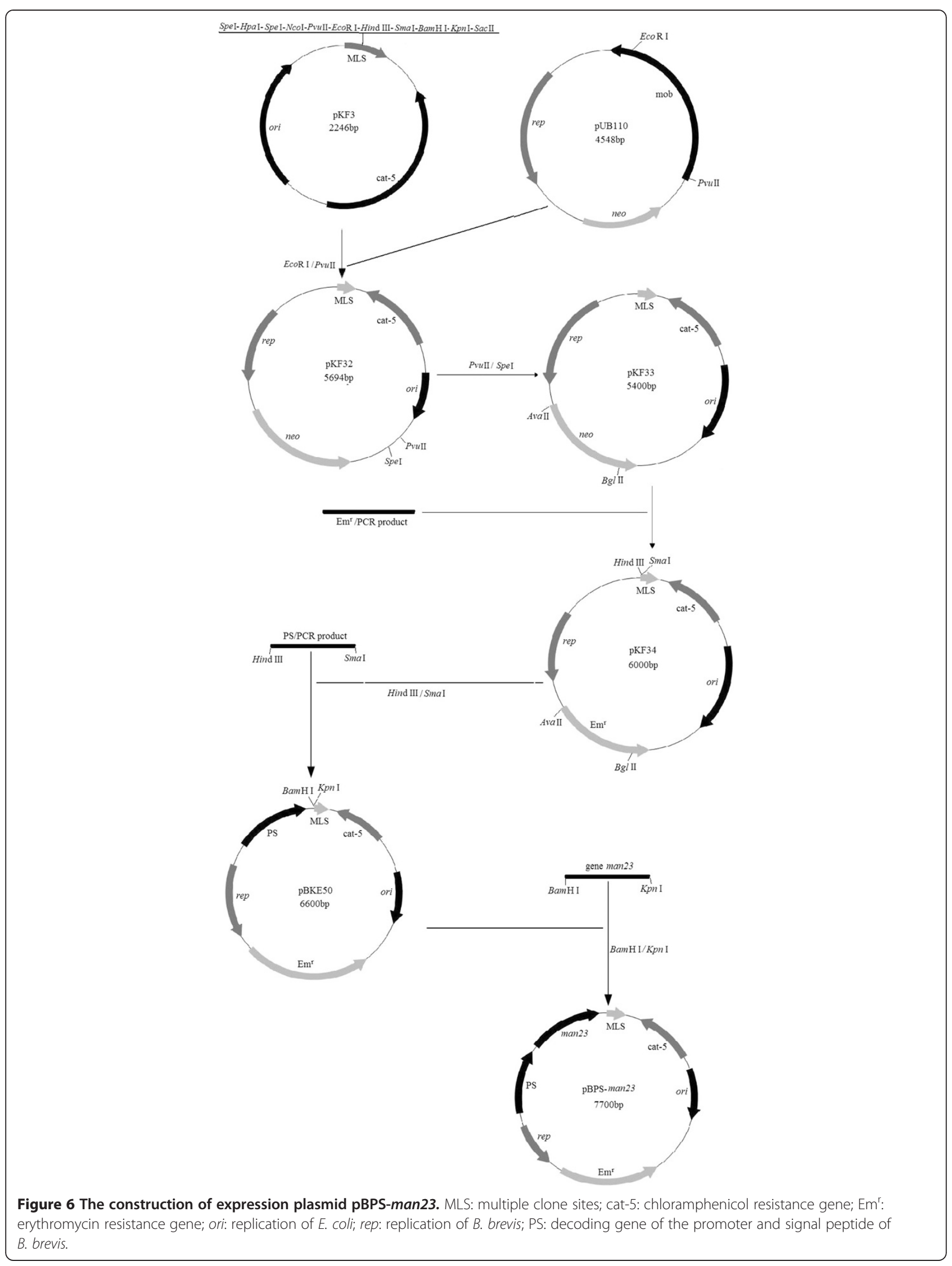


Specific activity of mannanase (units per milligram) $=$ $5.56 \mathrm{C}_{\mathrm{e}} \mathrm{V}_{\mathrm{de}}^{2} / \mathrm{C}_{\mathrm{p}} \mathrm{V}_{\mathrm{je}} \mathrm{V}_{\mathrm{s}} \mathrm{t}$

$\mathrm{C}_{\mathrm{p}}$ amount of total proteins, $\mathrm{mg}$

The optimal temperature of mannanase Man23 was evaluated by the activity assay at $20,30,40,50,60,70$, $80,90^{\circ} \mathrm{C}$ for $10 \mathrm{~min}$. The assay was performed with $1 \mathrm{ml}$ mannanase solution $(\sim 1.0 \mathrm{mg} / \mathrm{ml})$ at $\mathrm{pH} 6.8$ and 50 $\mathrm{mmol} / \mathrm{L}$ phosphate buffer.

The optimal $\mathrm{pH}$ was evaluated by the activity assay in different $\mathrm{pH}$ values of $50 \mathrm{mmol} / \mathrm{L}$ phosphate buffer for $10 \mathrm{~min}$ and temperature was maintained at $50^{\circ} \mathrm{C}$. The mannanase amount was same as above.

Thermostability of mannanase Man23 was measured by incubating the samples for 20 hours at different temperatures and then plotting the residual activity versus the incubation time. The $\mathrm{pH}$ tolerance was measured by incubating the samples for 20 hours at different $\mathrm{pH}$ and then plotting the residual activity versus the incubation time.

\section{Electrophoresis analysis of protein samples}

The proteins extracted from wild-type, B. bacillus WB600 and $B$. brevis were analyzed by SDS-PAGE [45]. Marker was purchased from TIANGEN biotech co., LTD and it includes six bands of 97.4, 66.2, 43.0, 31.0, 20.1 and $14.4 \mathrm{Ku}$.

\section{Statistical analysis}

Data were presented as the mean \pm standard error of the mean. Results were compared with the analysis of variance and Fisher's protected least-significant difference tests, with a significance of $P<0.05$.

\section{Competing interests}

The authors declare that they have no competing interests.

\section{Authors' contributions}

$\mathrm{HZ}$ conceived and designed the study, carried out the molecular genetic studies, and drafted the manuscript. $Y Y$ and $X N$ carried out the genetic studies and the determinations. WY participated in determinations and performed the statistical analysis. YW conceived of the study, participated in its design and helped to draft the manuscript. $H Z, Y Y, X N, W Y$ and $Y W$ reviewed and edited the manuscript. All authors read and approved the final manuscript.

Received: 12 June 2013 Accepted: 4 September 2013

Published: 8 September 2013

\section{References}

1. Hilge M, Gloor SM, Rypniewski W, Sauer O, Heightman TD, Zimmermann W, Winterhalter K, Piontek K: High-resolution native and complex structures of thermostable beta-mannanase from thermomonospora fusca-substrate specificity in glycosyl hydrolase family 5. Structure 1998, 6(11):1433-1444.

2. Songsiriritthigul C, Buranabanyat B, Haltrich D, Yamabhai M: Efficient recombinant expression and secretion of a thermostable $\mathrm{GH} 26$ mannan endo-1,4-beta-mannosidase from Bacillus licheniformis in Escherichia coli. Microb Cell Fact 2010, 11(9):20-33.

3. Yoshida S, Sako Y, Uchida A: Cloning, sequence analysis, and expression in Escherichia coli of a gene coding for an enzyme from Bacillus circulans K-1 that degrades guar gum. Biosci Biotechnol Biochem 1998, 62(3):514-520.
4. Tamaru Y, Araki T, Morishita T, Kimura T, Sakka K, Ohmiya K: Cloning, DNA sequencing, and expression of the beta-1,4-mannanase gene from a marine bacterium, Vibrio sp. strain MA-138. J Ferment Bioeng 1997, 83:201-205.

5. Filichkin SA, Leonard JM, Monteros A, Liu P-P, Nonogaki H: A novel endo- $\beta$-mannanase gene in tomato LeMAN5 is associated with anther and pollen development. Plant Physiol 2004, 134:1080-1087.

6. Bourgault R, Bewley JD: Variation in its C-terminal amino acids determines whether endo-beta-mannanase is active or inactive in ripening tomato fruits of different cultivars. Plant Physiol 2002, 130(3):1254-1262.

7. Larsson AM, Anderson L, Xu B: Three-dimensional crystal structure and enzymic characterization of beta-mannanase Man5A from blue mussel Mytilus Edulis. J Mol Biol 2006, 357(5):1500-1510.

8. Stålbrand H, Saloheimo A, Vehmaanpera J, Henrissat B, Penttila M: Cloning and expression in Saccharomyces cerevisiae of a Trichoderma reesei betamannanase gene containing a cellulose binding domain. Appl Environ Microbiol 1995, 61:1090-1097.

9. Nazina TN, Tourova TP, Poltaraus AB, Novikova EV, Grigoryan AA, Ivanova AE, Lysenko AM, Petrunyaka W, Osipov GA, Belyaev SS, Ivanov MV: Taxonomic study of aerobic thermophilic bacilli: descriptions of geobacillus subterraneus gen. nov., sp. nov. and Geobacillus uzenensis sp. Nov. from petroleum reservoirs and transfer of Bacillus stearothermophilus, Bacillus thermocatenulatus, Bacillus thermoleovorans, Bacillus kaustophilus, Bacillus thermodenitrificans to Geobacillus as the new combinations G. stearothermophilus, G. th. Int J Syst Evol Microbiol 2001, 51:433-466.

10. Simonen M, Palva I: Protein secretion in Bacillus species. Microbiol Rev 1993, 57:109-137.

11. Harwood CR: Bacillus subtilis and its relatives: molecular biological and industrial workhorses. Trends Biotechnol 1992, 10:247-256.

12. Klessen C, Malke H: Expression of the streptokinase gene from Streptococcus equisimilis in Bacillus subtilis. J Basic Microbio/ 1986, 26:75-81.

13. Wu XC, Lee W, Tran L, Wong SL: Engineering a Bacillus subtilisexpressionsecretion system with a strain deficient in six extracellular proteases. J Bacteriol 1991, 173:4952-4958.

14. Udaka S, Yamagata H: High level secretion of heterologous proteins by Bacillus brevis. Methods Enzymol 1993, 217:23-33.

15. Kajino T, Saito Y, Asami O, Yamada Y, Hirai M, Udata S: Extracellular production of an intact and biologically active human growth hormone by Bacillus brevis. J Ind Microbiol Biotechnol 1997, 19:227-231.

16. Zhang X, Tian Z, Wu Y, Zhou S, Kang D: The cloning and expression of $\beta$-mannanase gene in E. coli. Journal of Hunan Agricultural University (Natural Sciences) 2005, 31(6):605-608.

17. Henrissat B, Davies G: Structural and sequence-based classification of glycoside hydrolases. Curr Opin Struct Biol 1997, 7(5):637-644.

18. Katrolia P, Yan Q, Zhang P, Zhou P, Yang S, Jiang Z: Gene cloning and enzymatic characterization of an alkali-tolerant endo-1,4- $\beta$-mannanase from Rhizomucor miehei. J Agric Food Chem 2013, 61(2):394-401.

19. Vu TT, Quyen DT, Dao TT, Nquyen ST: Cloning, high-level expression, purification, and properties of a novel endo-beta-1,4-mannanase from Bacillus subtilis G1 in Pichia pastoris. J Microbiol Biotechnol 2012, 22(3):331-338

20. Politz O, Krah M, Thomsen KK, Borriss R: A highly thermostable endo-(1,4)-beta-mannanase from the marine bacterium Rhodothermus marinus. Appl Microbiol Biotechnol 2000, 53(6):715-721.

21. Ethier N, Talbot G, Sygusch J: Gene cloning, DNA sequencing, and expression of thermostable beta-mannanase from Bacillus stearothermophilus. Appl Environ Microbiol 1998, 64(11):4428-4432.

22. Li Y, Yang P, Meng K, Wang Y, Luo H, Wu N, Fan Y, Yao B: Gene cloning, expression, and characterization of a novel beta-mannanase from Bacillus circulans CGMCC 1416. J Microbiol Biotechnol 2008, 18(1):160-166.

23. Huang $J$, Bao LX, Zou HY, Che SG, Wang GX: High-level production of a cold-active B-mannanase from Bacillus subtilis BS5 and its molecular cloning and expression. Mol Gen Mikrobiol Virusol 2012, 4:14-17.

24. Hatada Y, Takeda N, Hirasawa K, Ohta Y, Usami R, Yoshida Y, Grant WD, Ito $S$, Horikoshi K: Sequence of the gene for a high-alkaline mannanase from an alkaliphilic Bacillus sp. strain JAMB-750, its expression in Bacillus subtilis and characterization of the recombinant enzyme. Extremophiles 2005, 9(6):497-500.

25. Yoon KH, Lim BL: Cloning and strong expression of a Bacillus subtilis WL-3 mannanase gene in B. subtilis. J Microbiol Biotechnol 2007, 17(10):1688-1694. 
26. Chen X, Cao Y, Ding Y, Lu W, Li D: Cloning, functional expression and characterization of Aspergillus sulphureus beta-mannanase in Pichia pastoris. J Biotechnol 2007, 128(3):452-461.

27. Luo H, Wang Y, Wang H, Yang J, Yang Y, Huang H, Yang P, Bai Y, Shi P, Fan $Y$, Yao B: A novel highly acidic beta-mannanase from the acidophilic fungus Bispora sp. MEY-1: gene cloning and overexpression in Pichia pastoris. Appl Microbiol Biotechnol 2009, 82(3):453-461.

28. Luo $H$, Wang $K$, Huang $H$, Shi $P$, Yang $P$, Yao B: Gene cloning, expression, and biochemical characterization of an alkali-tolerant $\beta$-mannanase from Humicola insolens Y1. J Ind Microbiol Biotechnol 2012, 39(4):547-555.

29. Wang Y, Shi P, Luo H, Bai Y, Huang H, Yang P, Xiong H, Yao B: Cloning, over-expression and characterization of an alkali-tolerant endo- $\beta-1$, 4-mannanase from Penicillium freii F63. J Biosci Bioeng 2012, 113(6):710-714.

30. Lv J, Chen Y, Pei H, Yang W, Li Z, Dong B, Cao Y: Cloning, expression, and characterization of $\beta$-mannanase from Bacillus subtilis MAFIC-S11 in Pichia pastoris. Appl Biochem Biotechnol 2013, 169(8):2326-2340.

31. Christgau S, Kauppinen S, Vind J, Kofod LV, Dalbøge H: Expression cloning, purification and characterization of a beta-1,4-mannanase from Aspergillus aculeatus. Biochem Mol Biol Int 1994, 33(5):917-925.

32. Pan X, Zhou J, Tian A, Le K, Yuan H, Xue Y, Ma Y, Lu H: High level expression of a truncated $\beta$-mannanase from alkaliphilic Bacillus $\mathrm{sp}$. N16-5 in Kluyveromyces cicerisporus. Biotechnol Lett 2011, 33(3):565-570.

33. Doi RH, Wong SL, Kawamura F: Potential use of Bacillus subtilis for secretion and production of foreign proteins. Trends Biotechnol 1986, 9(4):232-235.

34. Chang S: Engineering for protein secretion in gram-positive bacteria. Methods Enzymol 1987, 153:507-516.

35. Peng QZ, Zhang WC, Zhu HC: The construction of shuttle vectors of Brevibacillus brevis-Escherichia coli. Sheng Wu Gong Cheng Xue Bao 2002, 18(4):438-441.

36. Dong X: Systematic determination manual of common bacteria. Beijing: Science Press; 2001.

37. Sambrook J, Russell DW: Molecular cloning: a laboratory manual. New York: Cold Spring Harbor Laboratory Press; 2001

38. Ausubel FM, Brent R, Kingston RE, Moore DD, Seidman JG, Smith JA, Struhl K: Short protocols in molecular biology. USA: John Wiley \& Sons Inc; 2002.

39. Hashimoto-Gotoh T, Tsujimura A, Kuriyama K, Matsuda S: Construction and characterization of new host-vector systems for the enforcement-cloning method. Gene 1993, 137(2):211-216.

40. McKenzie T, Hoshino T, Tanaka T, Sueoka N: The nucleotide sequence of pUB110: some salient features in relation to replication and its regulation. Plasmid 1986, 15:93-103.

41. Takagi H, Kadowaki K, Udaka S: Screening and characterization of protein-hyper producing bacteria without detectable exoprotease activity. Agric Biol Chem 1989, 53:691-699.

42. Marshak DR, Kadonaga JT, Burgess RR, Knuth MW, Brennan WA, Lin S: Strategies for protein purification and characterization: a laboratory course manual. New York: Cold Spring Harbor Laboratory Press; 1996.

43. Hogg D, Woo EJ, Bolam DN, Mckie VA, Gilbert HJ, Pickersqill RW: Crystal structure of mannanase 26a from Pseudomonas Cellulosa and analysis of residues involved in substrate binding. J Biol Chem 2001, 276(33):31186-31192.

44. Sabathe F, Belaich A, Soucaille P: Characterization of the cellulolytic complex (cellulosome) of Clostridium acetobutylicum. FEMS Microbiol Lett 2002, 217(1):15-22.

45. Guo Y: A laboratory manual of protein electrophoresis. Beijing: Science Press; 1999.

doi:10.1186/1475-2859-12-78

Cite this article as: Zhou et al: Comparison of expression systems for the extracellular production of mannanase Man23 originated from Bacillus subtilis B23. Microbial Cell Factories 2013 12:78.

\section{Submit your next manuscript to BioMed Central and take full advantage of:}

- Convenient online submission

- Thorough peer review

- No space constraints or color figure charges

- Immediate publication on acceptance

- Inclusion in PubMed, CAS, Scopus and Google Scholar

- Research which is freely available for redistribution

Submit your manuscript at www.biomedcentral.com/submit 